\title{
Foreword
}

\section{Jagdish Bhagwati}

Max Kreinin, as all his friends call him, is one of the most creative and influential international economists of his generation, which happens to be the same as mine. Who has not used his celebrated textbook? And who has not profited from the steady stream of professional contributions that have marked his prolific career?

Max's range has also been tremendous, though we know him best from his seminal articles on economic integration. I have learnt from him also when we disagreed, as on whether Japanese entrepreneurs displayed an unjustified bias towards buying from Japanese sources; he was always a tough opponent whom one opposed only to profit from the exchange.

Even as we honor him with this Festschrift, splendidly edited by his student Michael Plummer, we know that he will continue for several more years to write and illuminate our understanding of international trade and even finance. His voice and his pen are as strong as ever. In honoring him, we also honor a warm and generous teacher and friend.

Jagdish Bhagwati, Columbia University 